\title{
Pendampingan Publikasi Online Situ Pengasinan, Sawangan, Depok, Jawa Barat
}

\author{
Zaenal Abidin Eko Putro ${ }^{1}$, Ade Haryani ${ }^{2}$, Pradiptia Wulan Utami ${ }^{3}$, Djony Herfan ${ }^{4}$ \\ ${ }^{1,2,3,4}$ Prodi Penerbitan (Jurnalistik), Politeknik Negeri Jakarta \\ Jl GA Siwabessy, Kampus UI, Depok \\ email: 'zabiep@gmail.com, ${ }^{2}$ adeharyani2@gmail.com, ${ }^{3}$ pradiptiautami@gmail.com, ${ }^{4}$ johnherf@gmail.com
}

\begin{abstract}
Abstrak
Pengabdian kepada masyarakat merupakan salah satu muatan dari Tri Dharma Perguruan Tinggi, sebagaimana tertuang dalam Pasal 20 UU Nomor 20 Tahun 2003 tentang Sistem Pendidikan Nasional, serta Pasal 45 UU Nomor 12 Tahun 2012 tentang Pendidikan Tinggi. Fokus kegiatan pengabdian kepada masyarakat program studi Penerbitan (Jurnalistik) Politeknik Negeri Jakarta tahun 2016 yaitu membantu mempromosikan atau menguatkan publikasi Situ Pengasinan yang terletak di Kampung Poncol, Kelurahan Pengasingan, Kecamatan Sawangan, Kota Depok. Kegiatan ini dilaksanakan dengan melibatkan pihak sasaran yaitu aktivis FKH Pengasinan, setelah sebelumnya beraudiensi dengan Dinas KLH dan Disbudpar Kota Depok.

Tujuan program pengabdian masyarakat ini adalah untuk meningkatkan kemampuan aktivis FKH Pengasinan dalam rangka melakukan publikasi pariwisata Situ Pengasinan, sebab selama ini belum ditemukan situs website yang khusus menyiarkan dan menyebarluaskan informasi tentang pariwisata dan tentu juga pengelolaan lingkungannya pada situ ini. Adapun dampak jangka panjang (outcome) yang diharapkan antara lain untuk dilakukannya perbaikan dan pengembangan Situ Pengasinan ke depan sebagai lokasi pariwisata air.
\end{abstract}

Kata-kata kunci: pengabdian kepada masyarakat, sumberdaya alam, Situ, Ekowisata, pendampingan publikasi online.

\begin{abstract}
Community engagement is one of the three points of Tridharma of Higher Education, as it is cited at the Law No 20/2003 on National Education System and article 45 the Law No 12/2012 on Higher Education. The focus of community engagement actvity designed by Journalism Study Program, State Polytechnic of Jakarta in 2016 is to help to promote or to strenghten publication of Situ Pengasinan (Pengasinan Basin) which is located at Poncol village, Depok, West Java. To execute the program, Journalism study program of State Polytechnic of Jakarta collaborated with a targeted group, activists of Forum Komunitas Hijau (Green Commonity Forum) of Pengasinan, Depok. Selecting this group was endorsed by the office of Life Environment and Tourism of Depok government.

The aim of community servise is to strengthen the capacity of FKH' activists to build promotion and publication on Situ Pengasinan tourism. It is because of the absence of any official and authoritatice online publication of Situ Pengasinan tourism potency. It is expected that this program has an outcome to empower the development of Situ Pengasinan tourism in the future as one of the tourism destinations on water tourism in West Java.
\end{abstract}

Keywords: community service, natural resource, basin, ecotourism, online publication support 


\section{Pendahuluan}

Pengabdian masyarakat merupakan salah satu muatan dari Tri Dharma Perguruan Tinggi, sebagaimana tertuang dalam Pasal 20 UU Nomor 20 Tahun 2003 tentang Sistem Pendidikan Nasional, serta Pasal 45 UU Nomor 12 Tahun 2012 tentang Pendidikan Tinggi. Dalam praktiknya, kegiatan pengabdian kepada masyarakat dilakukan sebagai bentuk kepedulian insan perguruan tinggi (akademisi) yang ditujukan untuk pengembangan masyarakat di luar kampus. Kegiatan ini dapat diselenggarakan dalam berbagai cara, salah satunya memberikan pendampingan dan pelatihan kepada masyarakat sesuai dengan program studi atau jurusan masingmasing. Di tahun 2016, Program studi Jurnalistik (Penerbitan), Politeknik Negeri Jakarta, kembali meneruskan kegiatan pengabdian masyarakat yang secara rutin diselenggarakan setiap tahun. Fokus kegiatan Pengabdian Masyarakat program studi ini untuk tahun 2016 yaitu membantu mempromosikan atau menguatkan publikasi Situ Pengasinan yang terletak di Kampung Poncol, Kelurahan Pengasingan, Kecamatan Sawangan, Kota Depok.

Sebagai salah satu wilayah di Indonesia yang kaya akan keanekaragaman hayati, kaya sumber daya alam serta kemolekan alamnya, Propinsi Jawa Barat tentulah sangat berpotensi mengembangkan industri pariwisatanya. Sejak lama hal ini tersadari oleh pihak-pihak pemangku kepentingan di Jawa Barat yang dibuktikan telah tersusunnya dalam visi Jawa Barat seperti tertuang di dokumen Rencana Pembangunan Jangka Menengah Daerah (RPJMD) Jawa Barat 2013-2018, yang menyebutkan tujuh karakter untuk mencapainya. Pada visi Jawa Barat untuk menjadi provinsi unggulan tahun 2025 disebutkan tujuh karakter, yang mana pada poin enam dan tujuh menyebutkan pentingnya pengelolaan infrastruktur yang handal dan pengelolaan lingkungan yang berimbang untuk pembangunan berkelanjutan, serta perlunya pengembangan budaya lokal dan menjadi destinasi wisata dunia.

Seiring dengan hal itu, melihat potensi yang berpeluang besar seirama dengan poin enam dan tujuh di atas sangatlah penting. Misalnya dengan melihat situ-situ di Jawa Barat, khususnya di Kota Depok sebagai bagian dari Provinsi Jawa Barat. Keberadaan situ di wilayah Jawa Barat, khususnya Depok memang sangat dirasakan. Salah satunya Situ Pengasinan. Sebagai salah satu situs sumber daya alam dan potensi pariwisata alam yang dimilikinya, Situ Pengasinan yang terletak di kawasan Sawangan, Depok merupakan salah satu situ yang sangat produktif di Wilayah Jawa Barat. Ini artinya situ ini dirasakan keberadaannya di tengah-tengah masyarakat, baik sebagai wilayah penyangga (buffer zone) untuk irigasi ke wilayah DKI maupun sebagai arena piknik warga sekitar. Secara konkrit, dari situ ini sebagian masyarakat menjadikan sumber penghasilan ekonomi, baik sebagai lahan budidaya perikanan maupun sebagian memanfaatkannya sebagai sarana pariwisata. Fungsi situ yang sedemikian ini masih nyata di tengah masyarakat sekitar, seperti di Situ Pengasinan. Berdasarkan data yang ada, dari sekitar 30-an jumlah situ di Kota Depok, Situ Pengasinan ini termasuk situ yang paling diperhatikan baik oleh masyarakat maupun oleh pemerintah daerah (Pusporini, 2010).

Menurut informasi dari pejabat terkait di Dinas Lingkungan Hidup dan Dinas Pariwisata di lingkungan Pemkot Depok, pengelolaan dan pemanfaatan situ ini mendapat dukungan dari pemerintah. Dalam kesehariannya memang peran masyarakat lebih dominan, terutama masyarakat yang memanfaatakan sebagai lahan pencarian ekonomi dengan menawarkan layanan jasa wisata bebek air misalnya. Bantuan bebek air itu sendiri juga merupakan bantuan dari Dinas Pariwisata Pemkot Depok. Di samping itu, Pemkot Depok juga memberi perhatian terhadap pemanfaatan lahan di sempadan situ sebagai jogging track dengan menempatkan paving pada jogging track tersebut. Pendeknya, situ ini mendapat perhatian dari pemerintah, baik diri sisi pemeliharaan dan juga pemanfaatan situ untuk kepentingan masyarakat sekitar.

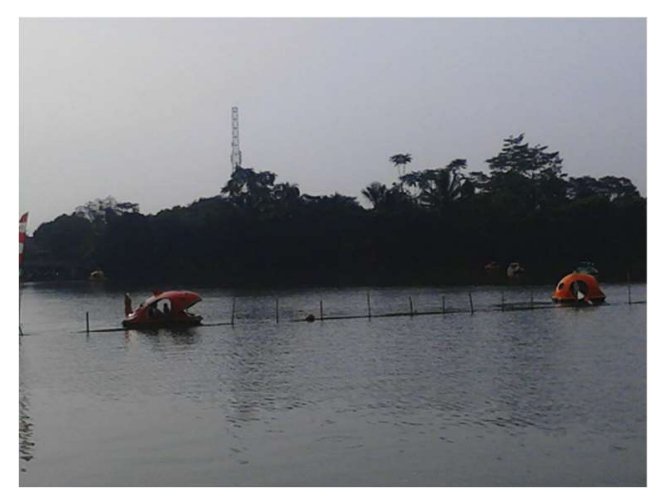

Sumber: Data primer (2016)

Gambar 1: Wisata air di Situ Pengasinan 


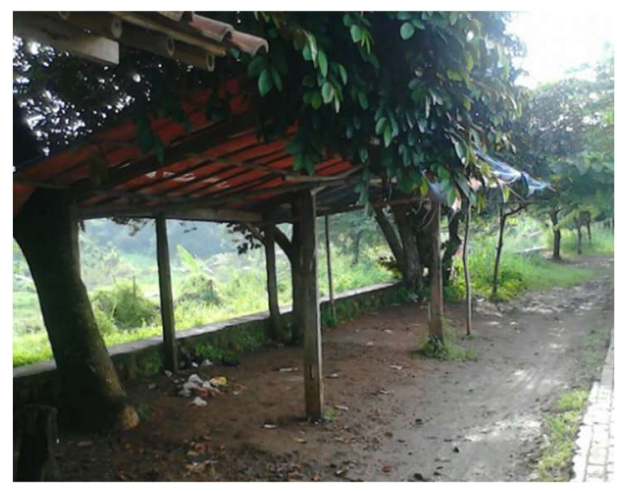

Sumber: Data primer (2016)

Gambar 2: Kondisi ruang terbuka teduh di pinggir Situ Pengasinan

Akan tetapi, di balik kondisi demikian ini, ternyata masih dirasakan belum adanya kesatuan visi di antara pemangku kepentingan, khususnya di kalangan pejabat Pemkot Depok yang diketahui dari kunjungan tim Prodi Penerbitan (Jurnalistik) Politeknik Negeri Jakarta ke Pemkot Depok, dalam pengembangan potensi pariwisata situ ini ke depan. Apalagi di tengah arus urbanisasi dan juga pengembangan perumahan di kawasan sekitar situ. Artinya, bagaimana pengelolaan dan pengembangan situ di tengah arus urbanisasi yang terus berlangsung masih dirasakan belum terlihat seperti apa rumusannya. Diasumsikan, jika pemerintah setempat belum memiliki kesatuan pandangan untuk pengelolaan dan pemanfaatan situ ini di tengah berbagai kondisi dan situasi tersebut, maka masyarakat sekitar pun juga dimungkinkan belum mempunyai kesatuan paham dan pandangan tentang isu yang sama.

Bahwa haruslah diakui, walaupun telah diperhatikan oleh pemerintah dan juga dimanfaatkan oleh masyarakat sekitar, ternyata masih ditemukan permasalahan terkait situ ini. Di antara problemnya adalah penataan sarana yang belum maksimal dan pengelolaan situ sebagai buffer zone masih sebatas menjaga pelestariannya. Problem yang tampak mendasar ialah belum tampak kuatnya rasa memiliki (sense of belonging) di kalangan masyarakat tentang keberadaan situ ini. Terutama sekali untuk mendukung kegiatan pariwasata. Hal ini tampak dari antara lain, minimnya rambu-rambu jalan menuju situ, papan reklame yang memberitahukan keberadaan situ dan juga akses jalan ke arah situ yang belum layak untuk kendaraan roda empat. Dibandingkan dengan situs wisata religi, Masjid Kubah Emas (Masjid Dian al Mahri) yang letaknya sekitar $7 \mathrm{~km}$ dari kawasan Situ Pengasinan ini, informasi tentang masjid itu lebih mengemuka, yang paling tidak terlihat dari papan petunjuk arah yang telah dapat dilihat sejak menuju Kecamatan Sawangan. Akibatnya keberadaan situ itu sendiri hanya diketahui oleh sebagian masyarakat lewat cara informasi informal dari mulut ke mulut dan belum terformat secara rapi. Dampak selanjutnya adalah pemanfaatan situ ini hanya menguntungkan bagi sebagaian kalangan, dan tidak menyeluruh pada masyarakat luas. Padahal jika dikelola lebih serius, bukan mustahil situs wisata religi Masjid Kubah Emas yang telah terkenal seantero negeri, dapat dirangkaikan dengan situs wisata air Situ Pengasinan. Minimnya kepedulian terhadap potensi di situ ini, baik sebagai situs pariwisata maupun sebagai sarana penyeimbang keberlangsungan pembangunan (sustainable development) berdasarkan pada upaya pelestarian lingkungan, maka perlulah pihak perguruan tinggi menyapa komunitas ini dan sedapat mungkin menjadi pendamping bagi pengembangan komunitas di sikitar situ ini, terutama di sektor pariwisatanya.

\section{Pendekatan Pendampingan}

Seperti diketahui, Kota Depok memiliki lokasi situ di beberapa tempat. Di samping terdapat situ yang sudah tidak berfungsi dan malah telah beralih fungsi, masih terdapat situ yang berjalan normal sesuai fungsinya. Bahkan, kini beberapa sudah meningkat fungsinya, bukan sebatas penampungan air sungai, namun menjadi lokasi pariwisata air. Hal ini seperti terjadi di Situ Pengasinan. Dilihat dari sisi lokasinya, lokasi Situ Pengasinan sekarang berada di tengah perkampungan warga. Letaknya tidak jauh dari kantor Kelurahan Pengasinan sekitar, 500 meter menyusuri jalanan yang tergolong tidak lebar. Jalanan memasuki lokasi situ dari jalan raya ini idealnya hanya dilalui kendaraan roda dua saja. Tidak jauh dari situ ini juga berdiri beberapa kompleks perumahan, seperti Perumahan Taman Melati, BSI, Villa Rizky Insani, dan lain-lain. Tidak heran, jika banyak warga memanfaatkan situ ini sebagai sarana pelepas ketegangan dengan memanfaatakan sarana yang ada seperti antara lain sepeda air.

Walaupun menjadi tujuan wisata air bagi masyarakat, kondisi sarana pendukung terutama jalan masuk tersebut hampir saja sama dengan kondisi publikasi situ ini sebagai lokasi alternatif pariwisata. Publikasi yang berbentuk bilboard secara fisik di pinggir jalan sejauh ini belum ditemukan, begitu pula publikasi lewat online, website. Dalam pengertian umum, paling tidak sejauh ini publikasi wisata di situ ini belum dikelola dengan baik. Atas kondisi demikian ini, maka Program Studi Penerbitan (Jurnalistik), Politeknik Negeri Jakarta (PNJ) tertarik untuk 
mendampingi masyarakat pengelola pariwisata di Situ Pengasinan, melalui kerjasamanya dengan organisasi Forum Komunitas Hijau (FKH) Pengasinan di bawah pimpinan Heri Syaifuddin (Heri Blangkon). Pilihan bekerja sama dengan lembaga ini atas saran dari Dinas KLH dan Dinas Pariwisata Pemkot Depok.

Program pengabdian kepada masyarakat Prodi D3 Penerbitan (Jurnalistik), Politeknik Negeri Jakarta ini dilaksanakan dengan melibatkan pihak sasaran yaitu aktivis FKH Pengasinan, setelah sebelumnya beraudiensi dengan Dinas KLH dan Disbudpar Kota Depok. Tim pengajar dari prodi ini berkunjung ke Kantor Dinas KLH dan Pariwisata Kota Depok yang terletak di Jalan Margonda, Depok pada Bulan Maret 2016. Kepada tim pengajar ini, pihak Dinas KLH menceritakan pengalamannya bekerja sama dengan FKH Pengasinan dalam rangka mengelola kelestarian lingkungan Situ Pengasinan. Diinformasikan kepada tim bahwa forum ini merupakan wadah bagi pemerhati dan pecinta lingkungan terutama Situ Pengasinan yang berasal dari berbagai latar belakang. Umumnya mereka adalah generasi muda, baik yang telah bekerja maupun sedang menempuh pendidikan di perguruan tinggi.

Tujuan program pengabdian masyarakat ini adalah untuk meningkatkan kemampuan aktivis FKH Pengasinan dalam rangka melakukan publikasi pariwisata Situ Pengasinan, sebab selama ini belum ditemukan situs website yang khusus menyiarkan dan menyebarluaskan informasi tentang pariwisata dan tentu juga pengelolaan lingkungannya pada situ ini. Adapun dampak jangka panjang (outcome) yang diharapkan antara lain untuk dilakukannya perbaikan dan pengembangan Situ Pengasinan ke depan sebagai lokasi pariwisata air. Penataan baik infrastruktur maupun manajemen pengeloaan merupakan dampak atau outcome selanjutnya yang diharapkan terwujud di masa datang atau jangka panjangnya. Selain dampak jangka panjang, dampak jangka pendek (output) diadakannya kegiatan pendampingan ini adalah terpelihara dan terawatnya lokasi Situ Pengasinan serta semakin menarik pengunjung situ ini sebagai tujuan wisata.

Perlu disebutkan juga, rangkaian kegiatan pengabdian masyarakat Program Studi Penerbitan (Jurnalistik) Politeknik Negeri Jakarta adalah sebagai berikut: pariwisata.
2. Merancang website pariwisata sesuai.muatan lokal pariwisata kota Depok.

3. Meningkatkan publikasi wisata air yang melibatkan Republika Traveling dan Disbudpar Depok.

4. Membentuk tim peliputan, pemotretan dan pemberitaan pariwisata Depok.

5. Mengunjungi situ yang potensial dikembangkan oleh tim website, Republika, Disbudpar Depok.

Untuk mencapai tujuan dan dampak seperti tersebut di atas, maka telah dilakukan serangkaian kegiatan yang pada intinya terkait dengan publikasi Situ Pengasinan. Salah satu pendekatan itu antara lain pendirian website dan pengelolaannya. Langkah awalnya adalah akan dibuatkan website, selanjutnya perlunya pengadaan komputer, tersedianya domain dan hosting, serta pemeliharaan jaringan. Untuk mendukung hal ini, perlu juga diadakan pelatihan jurnalistik singkat untuk mengisi website tersebut. Pelatihan ketrampilan jurnalistik di sini antara lain, metode penulisan berita, desain website, fotografi, pemahaman media online dan lain-lain.

Direncanakan, website ini nantinya berisikan kegiatan-kegiatan yang sifatnya mengandung unsur pariwisata di Situ Pengasinan. Info tentang kegiatan itu nantinya akan diunggah di dalam website. Penulisan laporan dan informasi kegiatan tersebut diharapkan dibuat oleh kelompok sasaran (FKH Pengsinan). Adapun untuk metode penulisan objek wisata air dalam website dilakukan oleh Prodi D3 Penerbitan (Jurnalistik) Politeknik Negeri Jakarta. Nantinya, Prodi D3 Penerbitan (Jurnalistik)lah yang akan mengelola website tersebut sebagai realisasi bentuk kerja sama dengan mitra luar kampus. Selain itu, secara praktis website tersebut juga menjadi wahana pemagangan bagi para mahasiswa.

\section{Kerangka Teori}

Situ Pengasinan terletak di Kampung Poncol, Kelurahan Pengasingan, Kecamatan Sawangan, Kota Depok, Propinsi Jawa Barat. Luas situ ini kurang lebih 6 hektar. Sumber air Situ Pengasinan berasal dari mata air dan aliran Sungai Angke (Permana, 2003: 149). Berlokasi di tengah pemukiman warga, situ ini tidak jauh atau 
hanya sekitar 300 meter jaraknya dari kantor Kelurahan Pengasinan, melewati jalanan yang idealnya hanya dilalui kendaraan roda dua saja.

Suryadiputra (2005) yang dikutip Pusporini (2010: 16-17), menyatakan bahwa situ dapat dikategorikan sebagai salah satu jenis lahan basah (umumnya berair tawar) dengan sistem perairan yang tergenang. Situ dapat terbentuk secara buatan yaitu berasal dari dibendungnya suatu cekungan (basin) atau terbentuk secara alami karena kondisi topografi yang memungkinkan terperangkapnya sejumlah air. Fungsi situ secara umum adalah daerah konservasi sumberdaya air karena situ merupakan pemasok air ke dalam akifer yang dapat mencegah terjadinya intrusi air laut, peredam banjir, dan membantu memperbaiki mutu air permukaan melalui proses reaksi kimia-fisikbiologi yang berlangsung di dalamnya (dengan pengecualian zat pencemar yang masuk ke perairan situ). Di samping itu, situ juga berfungsi sebagai pengatur iklim mikro bagi daerah sekitar. Fungsi lainnya, situ dapat dimanfaatkan sebagai irigasi, perikanan dan rekreasi. Penambahan fungsi tersebut mampu mendorong pertumbuhan ekonomi masyarakat sekitar jika dikembangkan lebih lanjut secara bertanggungjawab dan berkelanjutan.

Dalam perkembangannya, fungsi Situ Pengsinan juga ternyata mengarah pada penyediaan jasa pariwisata. Di situ ini tersedia wahana bermain, seperti sepeda air berbentuk bebek, ikan, kuda laut, dan ada pula yang berbentuk angsa. Para pengunjung yang ingin berkeliling di pinggiran situ dapat memanfaatkan jogging track yang sekarang telah dilapisi paving. Selain itu di situ ini juga ditebarkan beragam jenis ikan, misalnya ikan gurame, mas, mujair, gabus, dan ikan lele. Pengunjung pun dapat mempelajari cara menanam, memelihara, dan mengembangkan tanaman hias yang disediakan di Gon Ku Nursery yang berada di area situ. Naman Jojon, pengurus Kelompok Sadar Pariwisata (Pokdarwis) Situ Pengasinan menyampaikan bahwa kelompoknya mendapatkan penghasilan setiap tahunnya antara Rp 40 - Rp 50 juta hasil dari mengelola pariwisata dan holtikultura di situ tersebut (Warta Depok, April 2016: 13).

Pemanfaatan situ seperti ini apabila ditinjau lebih jauh, maka upaya seperti di atas tidak jauh dari langkah pemanfaatan sumberdaya alam. Katili (1983) mendefinisikan sumberdaya alam adalah semua unsur tata lingkungan biofisik yang dengan nyata atau potensial dapat memenuhi kebutuhan manusia, atau dengan kata lain sumber daya alam merupakan semua bahan yang ditemukan manusia dalam alam, yang dapat dipakai untuk memenuhi segala kepentingan hidupnya (Astawa, et al, 2012: 44). Selanjutnya, keberadaan sumberdaya alam sebagai situs pariwisata ini juga telah diperkuat kedudukannya dalam sistem hukum di Indonesia. Undangundang Nomor 9 tahun 1990 tentang Pariwisata menyebutkan, pariwisata adalah segala sesuatu yang berhubungan dengan wisata, termasuk pengusahaan-pengusahaan objek dan daya tarik wisata beserta usaha-usaha yang terkait di bidang tersebut.

Dalam wacana serupa, demikian ini juga beririsan dengan apa yang disebut ekowisata. Menurut Somba (2014), rumusan ekowisata atau "ecotourism" sebenarnya sudah ada sejak 1987 yang dikemukakan oleh Hector CeballosLascurain yaitu wisata alam atau pariwisata ekologis, yang diartikan perjalanan ke tempattempat alami yang relatif masih belum terganggu atau terkontaminasi (tercemari) dengan tujuan untuk mempelajari, mengagumi dan menikmati pemandangan, tumbuh-tumbuhan dan satwa liar, serta bentuk-bentuk manifestasi budaya masyarakat yang ada, baik dari masa lampau maupun masa kini.

Dengan memperhatikan pengelolaan dan pemanfaatan Situ Pengasinan sebagai daerah tampungan air dan sarana wisata seperti di atas, maka tampak bahwa pariwisata di tempat itu melibatkan masyarakat sekitar. Dalam banyak kajian, salah satu model pengembangan pariwisata adalah pariwisata berbasis masyarakat. Pola pariwisata seperti ini dapat memberi berbagai keuntungan selain peningkatan pendapatan uang tunai, mendukung pembangunan berwawasan lingkungan hidup, pelestarian budaya lokal, pemberdayaan masyarakat, menambah sumber pendapatan masyarakat tanpa menciptakan ketergantungan pada satu usaha saja, dan pemerataan pendatapan di antara masyarakat. Untuk merealisasikannya, pengembangan pariwisata berbasis masyarakat menggunakan pendekatan kerjasama antarpara pihak, termasuk pemerintah, masyarakat, usaha pariwisata, LSM, perguruan tinggi dan lembaga penelitian. Dalam mengembangkan pariwisata berbasis masyarakat terutama pada tahap awal, pendampingan masyarakat dibutuhkan agar masyarakat terlibat dalam seluruh proses pengembangan mulai dari tahap perencanaan (Cifor, 2004: 1-2).

Keterlibatan pihak ketiga seperti diuraikan dalam pengembangan pariwisata berbasis masyarakat di atas, terutama kelompok intelektual, untuk peningkatan kesejahteraan dan keunggulan masyarakat Jawa Barat juga telah 
dikukuhkan dalam peraturan seperti yang tertuang dalam Keputusan Bersama Menteri Negara Riset dan Teknologi dengan Gubernur Jawa Barat bernomor 02/M/SKB/IV/2006 yang membuka bagi kerjasama di bidang ilmu pengetahuan dan teknologi. Konkritnya, kerjasama itu dimaksudkan untuk implementasi ilmu pengetahuan dan teknologi guna peningkatan daya saing Provinsi Jawa Barat. Pasal 6 tentang ruang lingkup kerjasama tersebut menyebutkan pengembangan teknologi sesuai dengan dinamika masyarakat. Artinya, dinamika pariwisata berbasis masyarakat seperti di Situ Pengasinan juga layak melibatkan kalangan pihak lain, selain pemerintah serta masyarakat sekitar.

\section{Pelaksanaan Program}

\section{Gambaran umum Situ Pengasinan}

Bagi warga Kelurahan Pengasinan, Situ Pengasinan seakan tidak terpisahkan dari kesehariannya. Apalagi di sekitar situ juga terdapat empang yang cukup luas, tempat para pengusaha ikan menyewa maupun menyewakan empangnya. Jenis-jenis ikan yang dapat dikonsumsi seperti Ikan Mujair, Gurame, Mas, dan Lele paling banyak dipelihara di empang sekitar situ ini. Di samping juga terdapat beberapa areal pemancingan yang disewakan kepada pengunjung.

Di Situ seluas 6 hektare ini pada saat ini masih tampak pemandangan alam yang asri. Menariknya, di situ ini tersedia wahana bermain, seperti sepeda air berbentuk bebek, ikan, kuda laut, dan ada pula yang berbentuk angsa. Di samping itu, para pengunjung yang ingin berkeliling di pinggiran situ dapat memanfaatkan jogging trek yang sekarang telah dilapisi paving block. Bagi pengunjung yang hobi memancing dapat menyalurkannya sambil duduk di pinggiran situ. Di Situ Pengasinan ditebarkan beragam jenis ikan, misalnya ikan gurame, mas, mujair, gabus, dan ikan lele. Sekarang pengunjung pun dapat mempelajari cara menanam, memelihara, dan mengembangkan tanaman hias yang disediakan di Gon $\mathrm{Ku}$ Nursery yang berada di area situ. Berdasarkan data sejauh ini yang diberikan pihak Kelompok Sadar Pariwisata (Pokdarwis) Situ Pengasinan, kelompok ini mendapatkan penghasilan setiap tahunnya antara Rp 40 - Rp 50 juta.

Ketika dilakukan observasi lapangan untuk kepentingan kegiatan pengabdian Prodi D3 Penerbitan (Jurnalistik), Politeknik Negeri Jakarta baru-baru ini, kondisi di atas masih relatif sama. Saat ini dapat dilihat masih berjalannya wisata air di situ tersebut. Begitu pula tersedianya lapaklapak penjaja makanan di sekitar situ. Pengunjung pun juga masih ramai menikmati wisata air di atas sepeda air beraneka bentuk. Anak-anak didampingi orang dewasa berkeliling di atas air situ dengan menaiki sepeda air berbentuk bebek untuk mengayuh selama lebih kurang 30 menit. Corong speaker akan memanggil jika penyewa melewati batas waktu 30 menit yang telah ditentukan pengelola. Di setiap sepeda air itu terdapat angka, sehingga pengelola hanya menyebutkan angka sepeda air itu untuk segera berlabuh ke dermaga.

Sebagaimana disebutkan di atas, tujuan program pengabdian masyarakat ini adalah untuk meningkatkan publikasi pariwisata Situ Pengasinan yang sayangnya sampai pelaksanaan pengabdian kepada masyarakat ini belum terealisir. Sejauh ini, belum tersedia website yang dianggap "otoritatif" untuk memperkenalkan situs pariwisata ini secara lengkap dan menyeluruh. Informasi yang ada tentang kondisi pariwisata situ ini masih sporadis sifatnya yang dimuat di berbagai website dari domain yang tidak berbayar (misalnya blogspot). Di samping itu, update informasinya pun juga masih terbatas.

\section{Kegiatan Pengadian}

Pengabdian kepada masyarakat Prodi Penerbitan (Jurnalistik), Politeknik Negeri Jakarta menyasar kalangan mahasiswa dan fresh graduate yang dianggap cakap dalam melakukan aktivitas dan mampu menjalankan fasilitas Information and Communication Technologies (ICTs). Mereka yang tergabung dalam peserta pendampingan melalui skema pengabdian kepada masyarakat ini tergabung dalam Forum Komunitas Hijau (FKH) Pengasinan yang sekretariatnya berada di Joglo Pengasinan, Sawangan, persis di tepi Situ Pengasinan. Oleh karena itu, seleksi peserta lebih banyak dilakukan oleh pihak FKH Situ Pengasinan. Adapun pihak Prodi Penerbitan (Jurnalistik), Politeknik Negeri Jakarta hanya berkoordinasi dengan pengurus FKH yang dikomando Heri Syaifuddin (biasa dipanggil Heri Blangkon).

Kegiatan pendampingan itu dilakukan secara penuh dalam satu hari dengan materi yang disiapkan oleh Prodi Penerbitan (Jurnalistik), Politeknik Negeri Jakarta. Kegiatan dilaksanakan pada Bulan September 2016. Materi yang diberikan disusun sedemikian rupa, sehingga dianggap dapat terserap dengan baik oleh masyarakat dampingan (peserta). Materi tentang 
publikasi secara online tersusun atas penguatan konten, yaitu berupa ketrampilan tulis menulis dan fotografi. Adapun pemanfaatan tekonologi digital menggunakan web diberikan setelah ketrampilan dasar di atas selesai disampaikan. Fasilitator atau penyampai materi umumnya para pengajar di Prodi Penerbitan (Jurnalistik), Politeknik Negeri Jakarta.

Dalam pelaksanaan kegiatan ini, semua peserta langsung berhadapan dengan komputer, yang mana satu peserta satu komputer. Oleh sebab itu, hal ini dapat dilihat sebagai upaya penyampaikan materi secara efektif karena memadukan antara teori dan praktik. Mereka juga belajar sembari menjalankan aktivitas seperti yang disampaikan fasilitator, sehingga aktivitas tersebut dapatlah disebut sebagai learning by doing. Dua puluh lima peserta secara aktif melakukan kegiatan demikian, di tengah hembusan penyejuk adara yang membuat nyaman situasi kegiatan.

Bagi sebagaian peserta, penulisan merupakan hal baru, walaupun mereka pernah menulis karya ilmiah. Manulis naratif untuk kepentingan publikasi maupun advertorial ternyata tidak seperti menulis karya ilmiah dengan ketentuan serba baku. Menulis jenis ini cenderung ringan dan mengalir, tanpa pembaca mengernyitkan dahi untuk memahami substansi tulisan. Tulisan bersifat persuasif lebih ditonjolkan untuk mempengaruhi agar pembaca tertarik untuk datang ke Situ Pengasinan. Bagi peserta yang belum terbiasa menulis, hal demikian ini tentulah menjadi tantangan tersendiri. Namun mereka akan terus berusaha agar mampu menghasilkan tulisan seperti yang sampaikan fasilitator. Dipadu dengan kemampuan fotografi yang memadai serta terampil mengunggah tulisan dan foto ke website, mereka akan terampil untuk mengelola situs untuk kepentingan publikasi pariwisata.

Bagi penyelenggara, kegiatan seperti ini sebenarnya merupakan kegiatan reguler yang dilakukan secara rutin dalam perkuliahan. Bahan kajian yang disusun dalam matakuliah merupakan buah kajian yang mengombinasikan antara realitas di dunia industri media dan juga perkembangan ilmu pengetahuan di ranah perguruan tinggi. Oleh sebab itu, membawakan materi perkuliahan kepada khalayak di luar kampus merupakan tantangan tersendiri, sekaligus juga untuk menguji seberapa kokoh kurikulum yang telah disusun dan diajarkan kepada mahasiswa prodi ini secara reguler.
Peserta dimotivasi untuk dapat menjalankan publikasi mandiri secara online terhadap keberadaan dan potensi Situ Pengasinan kepada audience. Mereka diyakinkan dengan kemudahan teknologi media, terutama media sosial, mengunggah informasi terkait suatu potensi wisata yang dimiliki Situ Pengasinan itu menjadi lebih mudah. Publikasi tidak selalu dalam bentuk website dengan format berbayar, melainkan juga dapat menggunakan media sosial yang berbiaya lebih murah dan mudah untuk dijalankan.

\section{Analisis Teoretik}

Sumber daya alam merupakan semua bahan yang ditemukan manusia dalam alam, yang dapat dimanfaatkan untuk memenuhi segala kepentingan hidupnya. Pariwisata tentulah dapat disebut sebagai salah satu kebutuhan manusia itu. Keberadaan sumberdaya alam sebagai situs pariwisata yang dapat digunakan manusia ini juga telah diperkuat kedudukannya dalam sistem hukum di Indonesia. Undang-undang Nomor 9 tahun 1990 tentang Pariwisata menyebutkan, pariwisata adalah segala sesuatu yang berhubungan dengan wisata, termasuk pengusahaan-pengusahaan objek dan daya tarik wisata beserta usaha-usaha yang terkait di bidang tersebut.

Di dalam wilayah pariwisata (tourism) sendiri belakangan dikenal istilah ekowisata atau "ecotourism". Istilah ini dimaknai sebagai wisata alam atau pariwisata ekologis, berupa perjalanan ke tempat-tempat alami yang relatif masih belum terganggu atau terkontaminasi (tercemari) dengan tujuan untuk mempelajari, mengagumi dan menikmati pemandangan, tumbuh-tumbuhan dan satwa liar, serta bentuk-bentuk manifestasi budaya masyarakat yang ada, baik dari masa lampau maupun masa kini.

Dalam konteks Situ Pengasinan, pada situ ini juga terkandung sumberdaya alam yang perlu dimanfaatkan untuk kesejahteraan manusia. Situ ini menyajikan sumberdaya air yang menarik untuk dieksploitasi terkait dengan kemungkinan memberikannya sarana hiburan maupun pembelajaran alam. Di sinilah pentingnya melihat Situ Pengasinan sebagai situs sumberdaya alam yang berpotensi untuk menyuguhkan wisata bagi para pengunjungnya. Hal demikian ini pun telah disadari oleh kalangan pemangku kepentingan, termasuk masyarakat di sekitar situ. Di sinilah pentingnya pendampingan kepada masyarakat yang mengelola wisata di situ ini dilakukan. Di 
bagian ini pula para pelaku penyedia jasa wisata di situ ini perlu didukung untuk penguatan kemampuan dan kapabilitasnya untuk memanfaatkan sarana teknologi informasi untuk melancarkan dan mengembangkan industri wisata yang mereka geluti.

\section{Penutup}

Kegiatan pengabdian kepada masyarakat yang dilakukan Prodi Penerbitan (Jurnalistik) Politeknik Negeri Jakarta di tahun 2016 telah selesai dilakukan, dengan menggandeng Forum Komunitas Hijau (FKH) Pengasinan. Bentuk pendampingannya yaitu dengan memberikan asistensi pada pemanfaatan sarana publikasi online untuk penguatan publikasi Situ Pengasinan kepada khalayak luas. Pilihan topik ini terkait dengan area bidang kajian dan keahlian yang dikembangkan oleh prodi ini, sehingga sekaligus juga ingin melihat bagaimana bahan kajian di prodi ini diaplikasikan di masyarakat.

Namun karena keterbatasan tenggat waktu dan juga anggaran yang belum memungkinkan, maka kegiatan pendampingan tersebut lebih fokus pada kegiatannya dan juga komunikasi yang terjalin baik sebelum maupun setelah pelaksanaan kegiatan. Oleh sebab itu, perlu pendampingan lebih lanjut mengenai pemanfaatan website maupun platform media lain, termasuk media sosial untuk peningkatan publikasi Situ Pengasinan sebagai destinasi tujuan wisata air alternatif bagi warga Depok, khususnya serta Jawa Barat pada umumnya.

\section{Ucapan Terima Kasih}

Tim pengabdian kepada masyarakat Program Studi (Prodi) Penerbitan (Jurnalistik), Politeknik Negeri Jakarta perlu menyampaikan terima kasih sedalam-dalamnya kepada P3M PNJ atas dukungan finansialnya demi terlaksananya program pengabdian masyarakat. Terima kasih juga kepada para aktivis FKH Pengasinan yang telah bersedia menjadi mitra dalam pengabdian masyarakat prodi ini di tahun 2016.

\section{Daftar Pustaka}

[1] UU Nomor 20 Tahun 2003 tentang Sistem Pendidikan Nasional.

[2] UU Nomor 12 Tahun 2012 tentang Pendidikan Tinggi.

[3] Rencana Pembangunan Jangka Menengah Daerah (RPJMD) 2013-2018 Jawa Barat.

[4] Pusporini, Diah. 2010. Strategi Pengembangan Wisata Di Situ Pengasinan Kota Depok. Bogor: Tesis Sekolah Pascasarjana Institut Pertanian Bogor Bogor.

[4] Warta Depok, April 2016.

[5] Permana, Asep Arofah. 2003. Peranan Situ Terhadap Sistem Tata Air Kota Depok. Semarang: Tesis Program Pascasarjana Magister Perencanaan Pembangunan Wilayah dan Kota Universitas Diponegoro.

[6] Astawa, Ida Bagus Made. et al. Potensi Sumberdaya Alam dan Pengelolaannya untuk Mendukung Kehidupan Sosial Masyarakat Adat Kawasan Gunung Batur Bangli. Jurnal Socia, Vol. 11, No. 1 Mei 2012.

[7] Somba, Henry. R. Menanti Terwujudnya Manado Kota Model Ekowisata, dalam http://www.seputarsulut.com/menantiterwujudnya-manado-kota-model-ekowisata/ diakses tanggal 2 Februari 2017.

[8] Keputusan Bersama Menteri Negara Riset Dan Teknologi Dan Gubernur Jawa Barat Nomor 02/M/SKB/IV/2006 tentang Implementasi Ilmu Pengetahuan Dan Teknologi Untuk Peningkatan Daya Saing Provinsi Jawa Barat.

[9] Center For International Forestry Research (Cifor). Pembangunan Pariwisata Berbasis Masyarakat. Kabar No. 19, Juni 2004. 